\title{
THE EFFECT OF SOME PITUITARY HORMONES ON PROGESTERONE SYNTHESIS IN VITRO BY THE LUTEINIZED OVARY OF THE COMMON OPOSSUM (DIDELPHIS MARSUPIALIS VIRGINIANA)
}

\author{
BRIAN GOOK AND A. V. NALBANDOV \\ Department of Animal Science-Genetics, University of Illinois, \\ Urbana, Illinois, 61801
}

(Received 17th February 1967, revised 2nd May 1967)

\begin{abstract}
Summary. Luteinized ovaries of the opossum incubated in KrebsRinger bicarbonate buffer synthesized progesterone. Such synthesis could be enhanced by LH but not by FSH or prolactin. The ovaries did not incorporate acetate- $1-{ }^{14} \mathrm{C}$ into progesterone but did convert cholesterol-1,2- ${ }^{3} \mathrm{H}$ and pregnenolone- $7 \alpha-{ }^{3} \mathrm{H}$ into progesterone. $\mathrm{LH}$ tended to stimulate cholesterol conversion into progesterone but the effect was not significant. The thesis is advanced that, regardless of the luteotrophic or luteolytic mechanisms operating in different species, $\mathbf{L H}$ is steroidogenic. It is suggested that the control mechanisms for the oestrous cycle are simpler in marsupials than in other mammalian species and an understanding of the processes involved in marsupials would give a useful baseline for comparisons with other species.
\end{abstract}

\section{INTRODUGTION}

Life histories of corpora lutea vary greatly from species to species. A recent review has emphasized that the luteotrophic (or luteolytic) mechanisms regulating luteal persistence are similarly diverse (Short, 1967). In spite of the fact that different luteotrophic and luteolytic mechanisms appear to operate in rats, pigs, women and rabbits, $\mathrm{LH}$ has been shown to stimulate progesterone synthesis in vitro in luteal tissues obtained from these four species (Armstrong, O'Brien \& Greep, 1964; Cook, Kaltenbach, Norton \& Nalbandov, 1967; Rice, Hammerstein \& Savard, 1964; Gorski, Padnos \& Nelson, 1965). Similar results have been obtained with corpora lutea removed from cows and sheep (Mason \& Savard, 1964; Kaltenbach, Cook, Niswender \& Nalbandov, 1966).

In marsupials, luteotrophic mechanisms have not been extensively studied, but the life-span of the corpus luteum appears to be fixed. Thus, the duration of pregnancy is generally less than the length of the cycle (Sharman, Calaby \& Poole, 1965) and the removal of the uterus in the common opossum (Didelphis) and in the brush possum (Trichosurus) did not extend the period for which corpora lutea persisted (Hartman, 1925; Clark \& Sharman, 1965).

In this paper we describe experiments designed to test the proposition 
that, because LH appears to be steroidogenic, irrespective of the luteotrophic mechanism, it will stimulate steroid synthesis in luteal tissue derived from a marsupial, the opossum (Didelphis marsupialis virginiana $\mathrm{Kerr}$ ).

\section{Animals}

\section{MATERIALS AND METHODS}

Eight female opossums, captured in the vicinity of Urbana, Illinois, were housed individually in rabbit hutches. The animals, seven of which were immature (weighing 1 to $1.5 \mathrm{~kg}$ ) and one of which was fully grown (weighing $4.5 \mathrm{~kg}$ ), were each injected subcutaneously with 500 i.u. PMSG (Equinex, Ayerst) followed $72 \mathrm{hr}$ later by 250 i.u. HCG (Chorionic Gonadotropin, Upjohn).

\section{Tissue}

Six days after the HCG treatment the animals were anaesthetized by injecting sodium pentobarbital intraperitoneally at a dose of $25 \mathrm{mg} / \mathrm{kg}$ body weight. The ovaries were removed at laparotomy and placed immediately in ice-cold Krebs-Ringer bicarbonate buffer, $\mathrm{pH} 7 \cdot 4$. Each pair of ovaries gave eight tissue slices which were distributed between four beakers, each beaker receiving one slice from the outside and one from the inside of an ovary. The final tissue weight in each vessel was between 100 and $150 \mathrm{mg}$.

\section{Incubations}

Two experiments were conducted, the first utilizing three and the second five possums. In Exp. 1, the tissues were placed in beakers containing $5 \mathrm{ml}$ of Krebs-Ringer bicarbonate buffer, $10 \mathrm{mg}$ glucose and $100 \mu \mathrm{c}$ of sodium acetate- $1-{ }^{14} \mathrm{C}(53.0 \mathrm{mc} / \mathrm{m}-\mathrm{mole}$, New England Nuclear Corp.). To six of the vessels (two for each animal) $10 \mu \mathrm{g}$ of ovine LH (NIH-LH-sl0) was then added and the remaining six beakers served as controls.

In Exp. 2, three modifications of the incubation medium and four hormone treatments were used. Tissues from one animal were incubated in KrebsRinger bicarbonate buffer with no addition of radio-active substrate. Ovarian slices from a second animal (the fully-grown possum) were incubated in beakers containing $20 \mu \mathrm{c}$ of pregnenolone- $7 \alpha-{ }^{3} \mathrm{H}$ (16 c/m-mole, New England Nuclear Corp.). Tissues from the remaining three animals were incubated in $5 \mathrm{ml}$ buffer containing ' $T$ ween 80 ' and $50 \mu \mathrm{c}$ cholesterol-1,2- ${ }^{3} \mathrm{H}(12.6 \mathrm{c} / \mathrm{m}-\mathrm{mole}$, New England Nuclear Corp.). The buffer containing the radio-active cholesterol was prepared by dissolving the cholesterol in ether, shaking the ether with a $0.15 \%$ solution of 'Tween 80 ' in buffer, and then gently bubbling nitrogen through the mixture to evaporate the ether. In all cases, before the buffer solution was pipetted into the incubation vessels, a mixture of $95 \%$ oxygen- $5 \%$ carbon dioxide was bubbled through the solution for $30 \mathrm{~min}$. The buffer solution in all vessels contained $2 \mathrm{mg} / \mathrm{ml}$ glucose.

In this experiment, each of the five animals provided tissue for one vessel in each of the four treatments, control, LH, FSH and prolactin. The hormones, which were all of ovine origin (NIH-LH-s10; NIH-FSH-sl; Panlitar, Armour), were present at a concentration of $2 \mu \mathrm{g} / \mathrm{ml}$.

In both experiments the tissues were incubated for $3 \mathrm{hr}$ at 37 to $38^{\circ} \mathrm{C}$ as previously described (Cook et al., 1967). 


\section{Progesterone extraction and determination}

Progesterone was isolated by the method of Armstrong et al. (1964) with minor modifications reported previously (Cook et al., 1967). Briefly, the homogenized samples were extracted with ether and the progesterone was isolated from the extract using two-dimensional thin-layer chromatography on silica gel HF (Merck AG, Darmstadt) in the solvent systems iso-octane-ethyl acetate $(5: 2)$ and methylene chloride-ether $(5: 2)$. Known quantities of progesterone- ${ }^{3} \mathrm{H}$ (Exp. 1) or progesterone $-{ }^{14} \mathrm{C}$ (Exp. 2) were added to assess procedural losses which, for all samples, were less than $25 \%$. Radio-activity measurements were carried out using a Packard 3365 Tri-Carb liquid scintillation spectrometer which gave a counting efficiency of $65 \%$ for ${ }^{14} \mathrm{C}$ and $40 \%$ for ${ }^{3} \mathrm{H}$. Quantitation of progesterone was by use of a Beckman DB-G grating spectrophotometer coupled to a Beckman Model 1005 linear-log recorder. Each sample, dissolved in $95 \%$ ethanol, was scanned from 230 to $250 \mathrm{~m} \mu$ to establish that a good absorption peak was obtained, and the concentration of steroid was estimated by measuring the optical density at $240 \mathrm{~m} \mu$ on the tracing from the recorder.

\section{Other procedures}

The radio-active steroids were all examined chromatographically before use. Samples were developed on $50 \times 200 \mathrm{~mm}$ plates coated with silica gel GF (Merck AG, Darmstadt) in the system methylene chloride-ether (5:2) and then examined with a Packard 7201 radiochromatogram scanner. The progesterone- ${ }^{3} \mathrm{H}$ and the progesterone $-{ }^{14} \mathrm{C}$ were found to give only one peak and were used without further purification. The cholesterol $-{ }^{3} \mathrm{H}$, which was used as soon as it was received and which was synthesized immediately before it was delivered, was also found to be pure. A further check on this compound was made by developing a sample in the TLC system iso-octane-ethyl acetate $(5: 2)$. This again demonstrated a lack of contamination so the cholesterol was used without purification. The pregnenolone- ${ }^{3} \mathrm{H}$ was found to be seriously contaminated and was purified by chromatography in both the systems mentioned above before it was added to the incubation vessels.

Solvents were purified and glassware was cleaned as previously described (Cook et al., 1967). Statistical analysis was carried out by the method of least squares using the University of Illinois SSUPAC multiple regression programme for the IBM 7094 digital computer.

A small amount of ovarian tissue was taken from one of the animals in each experiment and fixed in Bouin's solution. It was sectioned, treated with Mallory's stain and examined to assess the effectiveness of the hormonal treatment of the animals.

\section{RESULTS}

The hormonal treatment of the animals gave ovaries that were well luteinized (Pl. 1, Fig. 1) and luteal cells that appeared normal (Pl. 1, Fig. 2).

Examination of the developed thin-layer plates under U.v. light revealed only two absorbent spots. One, which was very weak, had the mobility of 
$20 \alpha$ - or $20 \beta$-hydroxypregn-4-en-3-one. Studies are in progress to identify this compound and to detect and identify any other steroids which may have been synthesized during incubation and which were not revealed under U.v. light. The compound giving the second region of absorption had the chromatographic mobility of progesterone, and has been established to be progesterone. Table 1

TABle 1

EFFECT OF GONADOTROPHINS ON PROGESTERONE SYNTHESIS in vitro BY LUTEINIZED OPOSSUM OVARIES

\begin{tabular}{|c|c|c|c|c|c|c|}
\hline \multirow[b]{2}{*}{ Experiment } & \multirow[b]{2}{*}{$\begin{array}{l}\text { No. of } \\
\text { animals }\end{array}$} & \multicolumn{4}{|c|}{$\begin{array}{l}\text { Progesterone concentration }(\mu g / g) \\
\text { after incubation with: }\end{array}$} & \multirow[b]{2}{*}{$\begin{array}{c}\text { Standard error: } \\
\text { pooled estimate } \\
\text { (No. of flasks/ } \\
\text { treatment group) }\end{array}$} \\
\hline & & $\begin{array}{l}\text { No } \\
\text { addition }\end{array}$ & $\begin{array}{c}\mathcal{N} I H-L H-S 10 \\
\quad(2 \mu g / m l)\end{array}$ & $\begin{array}{c}\text { NIH-FSH-S1 } \\
\quad(2 \mu \mathrm{g} / \mathrm{ml})\end{array}$ & $\begin{array}{c}\text { NIH } \\
\text { prolactin } \\
(\text { Armour }) \\
(2 \mu g / m l)\end{array}$ & \\
\hline $\begin{array}{l}1 \\
2\end{array}$ & $\begin{array}{l}3 \\
5\end{array}$ & $\begin{array}{l}97 \cdot 0 \\
65 \cdot 2\end{array}$ & $\begin{array}{l}137 \cdot 8 * * * \\
88 \cdot 4 * *\end{array}$ & $\overrightarrow{75 \cdot 7}$ & $\overline{72 \cdot 1}$ & $\begin{array}{l}2 \cdot 97(6) \\
3 \cdot 67(5)\end{array}$ \\
\hline
\end{tabular}

** $P<0.01$ for LH versus control.

$* * * P<0.001$ for LH versus control.

shows the effect of the different treatments in Exps. 1 and 2 on the amount of this steroid that was present at the end of the incubation. LH is the only pituitary hormone that significantly changed the final progesterone concentration in the tissue.

Table 2 shows the effect of the pituitary hormones on the conversion of the

TABLE 2

THE EFFECT OF GONADOTROPHINS ON THE CONVERSION OF CHOLESTEROL-1, $2-{ }^{3} \mathrm{H}$ AND PREGNENOLONE-7 $\alpha-{ }^{3}$ H INTO PROGESTERONE BY LUTEINIZED OPOSSUM OVARIES

\begin{tabular}{|c|c|c|c|c|c|c|}
\hline \multirow[b]{2}{*}{ Substrate } & \multirow[b]{2}{*}{$\begin{array}{l}\text { No. of } \\
\text { animals }\end{array}$} & \multicolumn{4}{|c|}{ Conversion $\left(c p m^{*} / g\right)$ after incubation with: } & \multirow{2}{*}{$\begin{array}{c}\text { Standard error: } \\
\text { pooled estimate } \\
\text { (No. of flasks/ } \\
\text { treatment group) }\end{array}$} \\
\hline & & $\begin{array}{c}\text { No } \\
\text { addition }\end{array}$ & $\begin{array}{c}\mathcal{N} I H-L H-S 10 \\
\quad(2 \mu g / m l)\end{array}$ & $\begin{array}{c}\mathcal{N} I H-F S H-S 1 \\
\quad(2 \mu \mathrm{g} / \mathrm{ml})\end{array}$ & $\begin{array}{c}\text { NIH- } \\
\text { prolactin } \\
(\text { Armour }) \\
(2 \mu g / m l)\end{array}$ & \\
\hline $\begin{array}{c}\text { Cholesterol- } \\
1,2-{ }^{3} \mathrm{H}\end{array}$ & 3 & 49,174 & 55,326 & 47,948 & 47,344 & $4255(3)$ \\
\hline $\begin{array}{l}\text { Pregnenolone- } \\
\quad 7 \alpha-{ }^{3} \mathbf{H}\end{array}$ & 1 & $8.69 \times 10^{7} \dagger$ & $13.36 \times 10^{7} \dagger$ & $9.33 \times 10^{7 \dagger}$ & $9 \cdot 77 \times 10^{7 \dagger}$ & $-(1)$ \\
\hline
\end{tabular}

* cpm=counts/min.

$\dagger$ After chromatography in a third system following the two-dimensional system (see Table 3 ).

radio-active compounds to progesterone. None of the acetate- $1-{ }^{14} \mathrm{C}$ was incorporated into the steroid. LH may have stimulated cholesterol- ${ }^{3} \mathrm{H}$ conversion to progesterone but the effect was not significant with only three flasks per treatment. Pregnenolone $-{ }^{3} \mathrm{H}$ was converted into progesterone in high yield $(45 \%)$ but with only one flask per treatment, a discussion of differences would be rash. 
PIATE I

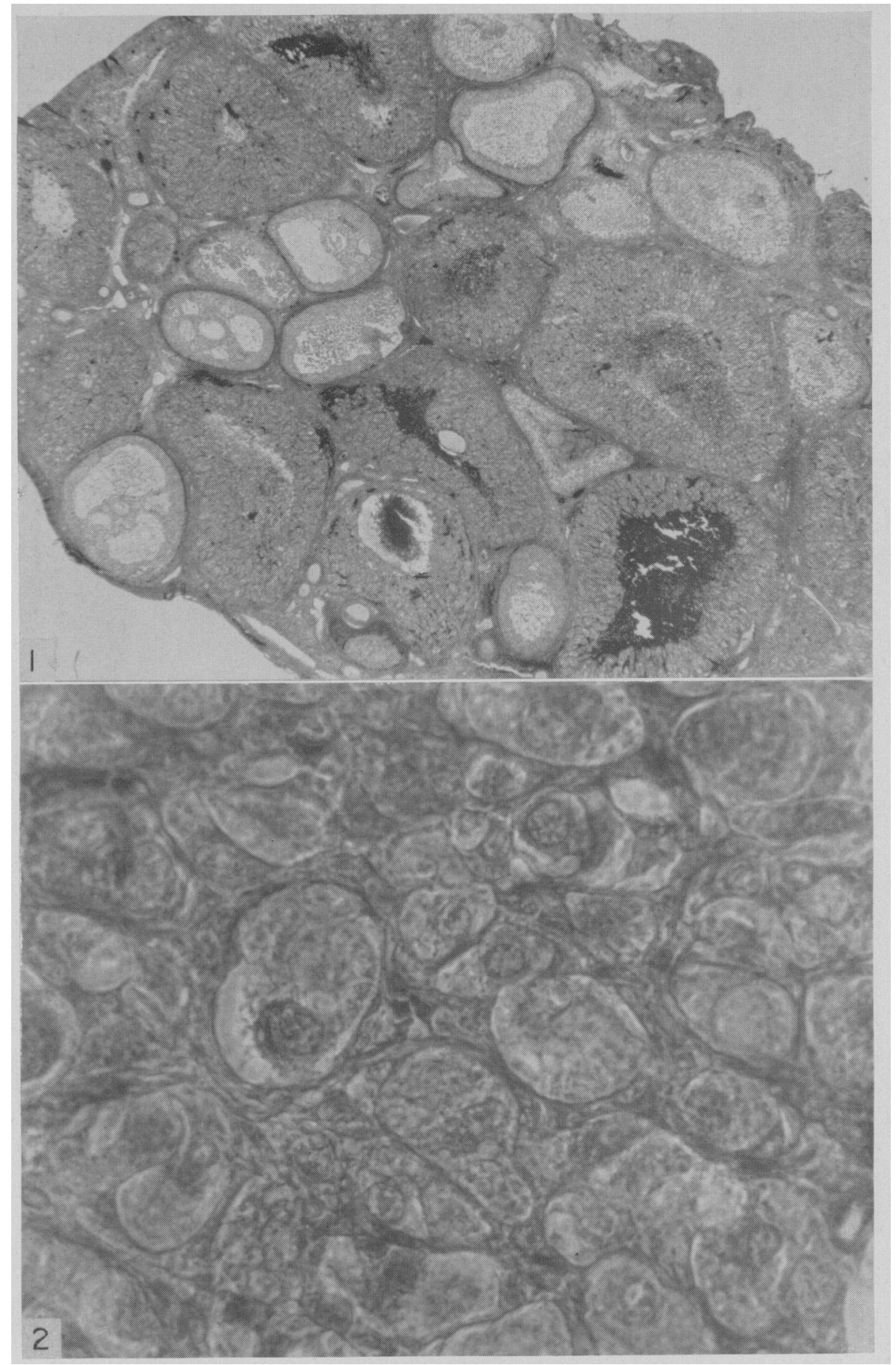

Fir. 1. A section of the luteinized ovary of the opossum $(-17 \cdot 5)$ showing corpora lutea. follicles and luteinized follicles. 'The classical results of limsi-He: treatment are clearly apparent.

Fic: 2. Luteal cells at high magnification, 560 . The tissue has the normal appearance of active corpora lutea. 


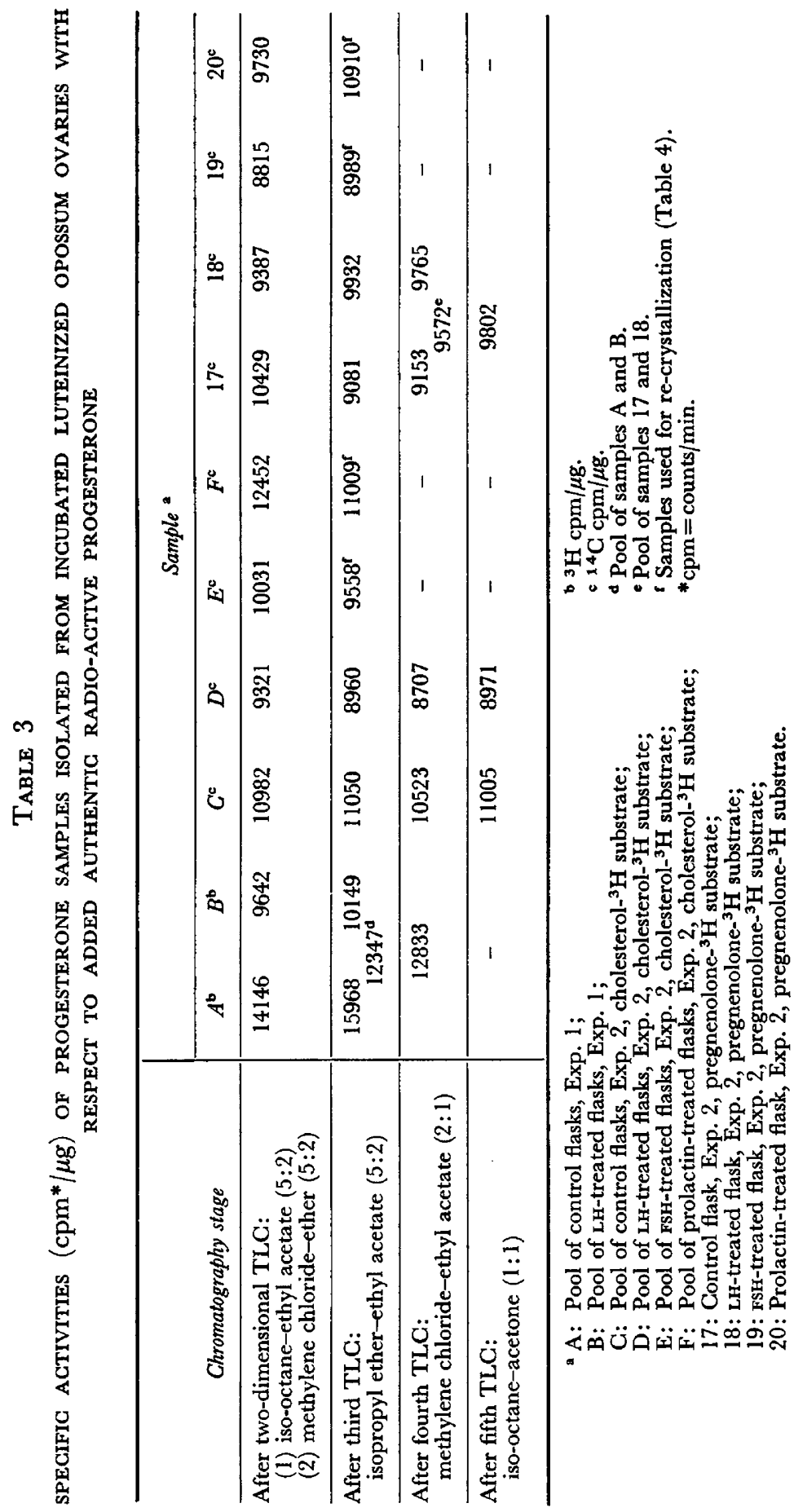


Initially, the compound isolated was judged to be progesterone by two criteria: (1) the radio-active tracer added to determine purification losses (progesterone- ${ }^{3} \mathrm{H}$ in Exp. 1 and progesterone $-{ }^{14} \mathrm{C}$ in Exp. 2) was present with the U.v.-absorbing material; and (2) the absorption peaks obtained from the recording spectrophotometer showed maxima for every sample the same as the maximum for progesterone $(240 \mathrm{~m} \mu)$. Further evidence for the chemical nature of the compound was obtained by: (1) re-chromatographing pooled and individual samples through many systems and demonstrating that the specific activity with respect to the added radio-active progesterone remained reasonably constant; and (2) re-crystallizing pooled and individual samples from Exp. 2 after the addition of pure crystalline progesterone, and demonstrating that the specific activity with respect to ${ }^{3} \mathrm{H}$ (representing progesterone produced from cholesterol and pregnenolone) did not change appreciably. The former procedure (Table 3 ) indicated that the U.v.-absorbing material initially isolated

\section{TABLE 4}

SPECIFIG AGTrvities (cpm*/mg) AFTER RE-GRYSTALlization OF PROGESTERONE- ${ }^{3}$ H ISOLATED FOLLOWING INCUBATION OF SLICES OF LUTEINIZED OPOSSUM OVARIES WITH CHOLESTEROL- ${ }^{3} \mathrm{H}$ OR PREGNENOLONE- ${ }^{3} \mathrm{H}$

\begin{tabular}{|c|c|c|c|c|c|c|c|c|}
\hline \multirow{4}{*}{$\begin{array}{l}\text { Purification } \\
\text { stage }\end{array}$} & \multicolumn{8}{|c|}{ Substrate } \\
\hline & \multicolumn{4}{|c|}{ Cholesterol-1,2- ${ }^{3} H$} & \multicolumn{4}{|c|}{ Pregnenolone $-7-{ }^{3} \mathrm{H}$} \\
\hline & \multicolumn{2}{|c|}{ Sample $E$} & \multicolumn{2}{|c|}{ Sample F } & \multicolumn{2}{|c|}{ Sample 19} & \multicolumn{2}{|c|}{ Sample 20} \\
\hline & Crystals & $\begin{array}{l}\text { Mother } \\
\text { liquor }\end{array}$ & Crystals & $\begin{array}{l}\text { Mother } \\
\text { liquor }\end{array}$ & Crystals & $\begin{array}{l}\text { Mother } \\
\text { liquor }\end{array}$ & Crystals & $\begin{array}{l}\text { Mother } \\
\text { liquor }\end{array}$ \\
\hline After carrier addition $\dagger$ & 34 & - & 31 & - & 8150 & - & 11000 & - \\
\hline $\begin{array}{l}\text { First re-crystallization } \\
\text { methanol-water }\end{array}$ & 29 & 33 & 31 & 31 & 8037 & 8771 & 10905 & 12950 \\
\hline $\begin{array}{l}\text { S econd re-crystallization } \\
\text { benzene-hexane }\end{array}$ & 33 & 36 & 33 & 38 & 7895 & 8286 & 10944 & 11012 \\
\hline $\begin{array}{l}\text { Third re-crystallization } \\
\text { acetone-iso-octane }\end{array}$ & 32 & 37 & 32 & 35 & 7932 & 7891 & 11077 & 10597 \\
\hline $\begin{array}{l}\text { Fourth re-crystallization } \\
\text { ethanol-water }\end{array}$ & 34 & 31 & 31 & 24 & 7892 & 7697 & 10841 & 11002 \\
\hline
\end{tabular}

$* \mathrm{cpm}=$ counts $/ \mathrm{min}$.

$\dagger 250 \mathrm{mg}$ of authentic progesterone added to samples taken from third thin-layer chromatography (Table 3).

was chemically pure, whereas the latter procedure (Table 4 ) demonstrated the radio-chemical purity of the isolated conversion products. The samples ultimately re-crystallized were chromatographed once after the two-dimensional thin-layer chromatography (Table 3 ) and this third chromatographic treatment eliminated 5 to $10 \%$ tritium contamination from those samples that had been incubated with pregnenolone- ${ }^{3} \mathrm{H}$. This purification is not apparent from an examination of either of the tables, but it obviously indicates a failure of the two-dimensional system to separate progesterone from pregnenolone completely.

These findings show that the major compound isolated from luteinized opossum ovaries was progesterone; that the progesterone was isolated in a state of adequate chemical and radio-chemical purity (except in the presence of 
added pregnenolone- ${ }^{3} \mathrm{H}$ ); and that progesterone synthesis in luteinized opossum ovaries is enhanced in the presence of $\mathrm{LH}$.

\section{DISCUSSION}

In conducting these experiments we would have preferred to use normally ovulating animals, but previous investigators have shown that, to maintain normal cycles in captive possums, it is necessary to keep them in pens of large area, one specific recommendation being $50 \mathrm{ft}^{2}$ (McGrady, 1938). Because we were not able to meet this exacting requirement we chose to induce corpora lutea in immature animals. Moore \& Morgan (1943) had shown that the ovaries of immature possums would respond to PMSG and we based our hormonal pre-treatment of the animals on their findings. Plate 1 indicates that we were quite successful in achieving the desired result.

Progesterone has been identified as the luteal hormone in only one other marsupial, the red kangaroo, Megaleia rufa (Lindner \& Sharman, 1966). The concentration of progesterone in the ovaries of this species was very low $(0.5$ to $3 \mu \mathrm{g} /$ pair $)$. We did not measure progesterone concentration before incubation, but concentrations after incubation were much lower than we have observed in pigs, sheep or cows under similar circumstances (Cook et al., 1967). In these latter species, however, only corpora lutea were incubated, and the presence of non-luteal tissue in the luteinized ovary of the opossum would be expected to reduce the overall progesterone concentration.

It is not clear why the preparation we used was not able to incorporate acetate- $1-{ }^{14} \mathrm{C}$ into progesterone. In all the studies mentioned in the introduction, the incorporation of radio-active acetate into progesterone in vitro was reported. It could be that the corpus luteum of the opossum does not develop the enzyme system for the conversion of acetate to acetyl-CoA or it could be that we used luteal tissue that was rather aged and had lost this metabolic capability, although it was still capable of converting cholesterol and pregnenolone to progesterone. A check of the sterol zone removed from the thin-layer plate indicated that very little ${ }^{14} \mathrm{C}$ was present. This suggested that a block in acetate incorporation occurred early in the pathway, hence the lack of progesterone- ${ }^{14} \mathrm{C}$ synthesis was not due to dilution by a large cholesterol pool. Hartman (1923) noted that the corpora lutea of the opossum reach full size by Day 3, and are maintained to only Day 7 to 8 of the oestrous cycle before a decline sets in. The organ has almost disappeared by 20 days. We used ovarian tissue 6 days after the animal had received HGG, and we assumed that this would be about 5 days after ovulation, i.e. in the middle of the period between the attainment of maximum size and the start of the decline. Tyndale-Biscoe (1963) demonstrated that, in the quokka (Setonix brachyurus), the luteal condition of the endometrium will appear and remain for the normal duration in an animal from which both ovaries are removed on Day 4 (of a 28-day cycle). He says "It is particularly remarkable that these changes appear in the uteri several days after the ovaries are removed and that the corpus luteum can exercise its full effect before its own growth is complete and while some of its luteal cells are actively dividing. This function of the corpus luteum has been 
fully simulated by the administration of progesterone to bilaterally ovariectomized animals." If the corpora lutea of the opossum are most active immediately after formation, which appears to be the case in the quokka, then it is conceivable that the tissue we used was senescent and therefore unable to metabolize acetate.

Nalbandov (1961) suggested that the secretion of a pituitary luteotrophin over a short period about the time of ovulation is sufficient to maintain the corpora lutea of the pig for their normal life-span during the oestrous cycle. No further release of pituitary luteotrophin would occur unless the animal became pregnant. In the opossum, there is little evidence to substantiate such a hypothesis, but teleologically a single output of hormone is an attractive idea because the corpora lutea of the cycle and pregnancy are one and the same thing, hence the need for a second release of luteotrophin would not arise. The observations of Tyndale-Biscoe (1963) in the quokka are consistent with the hypothesis that a single release of hormone ovulates the follicle, leads to its luteinization and then provides the necessary luteotrophic and steroidogenic stimulus for the corpus luteum. The hormone involved is most probably $\mathrm{LH}$ (we have demonstrated its steroidogenic potential in the opossum) and the phenomena considered above could be different manifestations of $\mathrm{LH}$ action. Marsupials could have the simplest form of ovarian regulation found in mammals, with one release of ovulating hormone triggering all the mechanisms necessary to complete an oestrous cycle, and with the uterus not involved in the control system. An understanding of the basic mechanisms of cycle control in marsupials could give more insight into the peculiar adaptations of other mammals, e.g. rats.

LH probably stimulated cholesterol conversion into progesterone in the opossum as it has been reported to do in other species (Hall \& Koritz, 1965) but the effect was not statistically significant, probably because insufficient flasks were included in the comparison. Species specificity in the hormonal preparations did not seem an important consideration in these experiments because PMSG, HCG and ovine LH were all effective under the conditions in which they were used.

It is conceivable, though unlikely, that the effects of $\mathbf{L H}$ in vivo may not parallel those in vitro. Eik-Nes \& Hall (1965) have reviewed the secretion of steroid hormones in vivo and it is clear that reproducible effects of LH have not been obtained. It is probable that, in many of the in-vivo experiments reported up to the present time, extraneous factors (anaesthesia, nervous responses, stress, etc.) have masked any effects of LH. These complications need to be circumvented before any definite conclusions can be drawn.

\section{ACKNOWLEDGMENTS}

We thank Dr G. C. Sanderson of the State of Illinois Natural History Survey for his advice on possum husbandry, Dr Jean Graber for preparing the histological sections, and Mrs Ruth Tyler and Mrs Natalie Sutterlin for technical assistance. This work was supported by grant No. AM 06976 of the National Institutes of Health. 


\section{REFERENCES}

Armstrong, D. T., O'Brien, J. \& Greep, R. O. (1964) Effects of luteinizing hormone on progestin biosynthesis in the luteinized rat ovary. Endocrinology, 75, 488.

Clark, M. J. \& Sharman, G. B. (1965) Failure of hysterectomy to affect the ovarian cycle of the marsupial Trichosurus vulpecula. F. Reprod. Fert. 10, 459.

Cook, B., Kaltenbach, C. C., Norton, H. W. \& Nalbandov, A. V. (1967) Synthesis of progesterone in vitro by porcine corpora lutea. Endocrinology, 81, 573.

EIK-Nes, K. B. \& Hall, P. F. (1965) Secretion of steroid hormones in vivo. Vitams Horm. 23, 153.

Gorski, J., PADnOs, D. \& Nelson, N. J. (1965) In vitro effects of luteinizing hormones on rabbit ovaries. Life Sci. 4, 713.

HALL, P. F. \& Koritz, S. B. (1965) Influence of interstitial cell-stimulating hormone on the conversion of cholesterol to progesterone by bovine corpus luteum. Biochemistry, 4, 1037.

Hartman, G. G. (1923) The oestrous cycle in the opossum. Am. F. Anat. 32, 353.

Hartman, G. G. (1925) Hysterectomy and the oestrous cycle in the opossum. Am. F. Anat. 35, 25.

Kaltenbach, C. G., Cook, B., Niswender, G. D. \& Nalbandov, A. V. (1966) Progesterone synthesis by ovine luteal tissue in vitro. 7 . Anim. Sci. 25, 926.

Lindner, H. R. \& Sharman, G. B. (1966) The pregnancy hormone in the red kangaroo (Megaleia rufa, Desm.). In 2nd Int. Congr. on Hormonal Steroids, p. 371. Eds. E. B. Romanoff and L. Martini. Int. Congr. Series No. 111, Excerpta Medica Foundation, Amsterdam.

Mason, N. R. \& Savard, K. (1964) Specificity of gonadotropin stimulation of progesterone synthesis in bovine corpus luteum in vitro. Endocrinology, 74, 664 .

McGrady, E. (1938) The embryology of the opossum. Am. anat. Mem. No. 16.

Moore, C. R. \& Morgan, C. F. (1943) First response of developing opossum gonads to equine gonatropic treatment. Endocrinology, 32, 17.

Nalbandov, A. V. (1961) Comparative physiology and endocrinology of domestic animals. Recent Prog. Horm. Res. 17, 119.

Rice, B. F., Hammerstein, J. \& Savard, K. (1964) Steroid hormone formation in the human ovary. II. Action of gonadotropins in vitro in the corpus luteum. F. clin. Endocr. Metab. 24, 606.

Sharman, G. B., Calaby, J. H. \& Poole, W. E. (1965) Patterns of reproduction in female diprotodont marsupials. F. Reprod. Fert. 9, 375.

Short, R. V. (1967) Reproduction. A. Rev. Physiol. 29, 373.

TyndAle-Biscoe, C. H. (1963) Effects of ovariectomy in the marsupial Setonix brachyurus. F. Reprod. Fert. 6, 25. 